Techniques \& Culture

Revue semestrielle d'anthropologie des techniques

31-32 | 1999

Dynamique des pratiques alimentaires

\title{
La table des saints
}

\section{Salvatore D'Onofrio}

\section{(2) OpenEdition}

Journals

Édition électronique

URL : https://journals.openedition.org/tc/398

DOI : $10.4000 /$ tc. 398

ISSN : 1952-420X

\section{Éditeur}

Éditions de l'EHESS

\section{Édition imprimée}

Date de publication : 1 avril 1999

ISSN : 0248-6016

\section{Référence électronique}

Salvatore D'Onofrio, «La table des saints», Techniques \& Culture [En ligne], 31-32 | 1999, mis en ligne le 26 octobre 2005, consulté le 29 septembre 2022. URL : http://journals.openedition.org/tc/398 ; DOI : https://doi.org/10.4000/tc.398

Ce document a été généré automatiquement le 29 septembre 2022.

Tous droits réservés 


\section{La table des saints}

Salvatore D'Onofrio 